\title{
ResearchArticle
}

\section{Chemical management of Alternaria leaf blight of Bt cotton}

\author{
G.H. ANIL, S.A. ASHTAPUTRE AND M.S.L. RAO
}

\section{SUMMARY}

Field experiment was conducted during Kharif 2006-07 and 2007-08 at Agricultural Research Station, Dharwad Farm for evaluation of different fungicides against Alternaria leaf blight of cotton. Fungicides viz., Hexaconazole $(0.1 \%)$, Tebuconazole $(0.1 \%)$, Propiconazole $(0.1 \%)$, Difenconazole $(0.1 \%)$, Penconazole $(0.1 \%)$, Propineb $(0.2 \%)$, Chlorothalonil $(0.2 \%)$, Carbendazim $(0.1 \%)$, Mancozeb $(0.2 \%)$ were sprayed after initiation of disease infection, three sprays were taken with 20 days interval and per cent disease index (PDI) was calculated after final spray. Propineb $(0.2 \%)$ was effective in controlling disease with per cent disease control of 76.09 followed by Difenconazole @ 0.1\% with 66.96 control.

Key Words : Alternaria blight, Cotton, Management, Foliar spray

How to cite this article : Anil, G.H., Ashtaputre, S.A. and Rao, M.S.L. (2017). Chemical management of Alternaria leaf blight of Bt cotton. Internat. J. Plant Sci., 12 (2): 267-270, DOI: 10.15740/HAS/IJPS/12.2/267-270.

Article chronicle : Received : 14.05.2017; Revised : 07.06.2017; Accepted : 22.06.2017 